\title{
Building Professional Identity During Pre-Service Teacher Education
}

Gemma Torres-Cladera ${ }^{1}$, Núria Simó-GiL ${ }^{1}$, Laura Domingo-Peñafiel ${ }^{\star 2}$, and Vanesa Amat-Castells ${ }^{1}$

$\approx \quad$ This article explores how university learning and the period of school placement can contribute to identity development understood as a dynamic and evolving process. From this perspective, we understand the teacher's professional identity as an ongoing process of interpretation and re-interpretation of experiences that are shaped in professional spaces of relationship with others, where each person makes different processes of identification, representations, and attributions, creating a spiral of continuous construction or reconstruction. It is thus a phenomenon of social interaction. Data collection involved eight students, their school tutors, and university teachers within the framework of 4th-year school placements. Data analysis was organised around three dimensions of the research project: the teacher him/herself, the bond between students and the educational community, and the relationship between the school and the university. The results highlighted the need to improve the practicum, especially at the university level. Both school and university tutors are crucial in promoting and guiding dialogical processes of knowledge construction with oneself, others, and the world. However, the university has an added responsibility in this key relational process; university tutors must improve their role as mediators between students and school tutors to contribute to the development of the teaching identity in a complex and dynamic way.

Keywords: initial training, practicum, teacher identity, tutoring, university

1 Faculty of Education, Translation and Human Sciences, University of Vic - Central University of Catalonia, Spain.

$2 *$ Corresponding Author. Faculty of Education, Translation and Human Sciences, University of Vic - Central University of Catalonia, Spain; laura.domingo@uvic.cat. 


\section{Oblikovanje poklicnih identitet v okviru izobraževanja učiteljev}

Gemma Torres-Cladera, Núria Simó-Gil, Laura Domingo-Peñafiel in Vanesa Amat-Castells

C Clanek preučuje, kako lahko univerzitetno učenje in obdobje šolske prakse prispevata $\mathrm{k}$ razvoju identitete, ki jo razumemo kot dinamičen in razvijajoč se proces. $S$ tega vidika učiteljevo poklicno identiteto razumemo kot stalen proces interpretacije in reinterpretacije izkušenj, ki se oblikujejo $\mathrm{v}$ profesionalnih prostorih odnosov $\mathrm{z}$ drugimi, pri čemer vsaka oseba izvaja različne procese identifikacije, reprezentacij in atribucij, kar ustvarja spiralo nenehne konstrukcije ali rekonstrukcije. Gre torej za pojav družbene interakcije. Pri zbiranju podatkov je sodelovalo osem študentov, njihovi šolski mentorji in univerzitetni učitelji v okviru šolske prakse 4. letnika. Analiza podatkov je bila organizirana okrog treh razsežnosti raziskovalnega projekta: učitelj sam, vez med učenci in izobraževalno skupnostjo ter odnos med šolo in univerzo. Rezultati so poudarili potrebo po izboljšanju prakse, zlasti na univerzitetni ravni. Šolski in univerzitetni učitelji so ključni pri spodbujanju in vodenju dialoških procesov konstrukcije znanja o sebi, drugih in o svetu, vendar ima univerza $\mathrm{v}$ tem ključnem odnosnem procesu dodatno odgovornost; univerzitetni tutorji morajo izboljšati svojo vlogo posrednikov med študenti in šolskimi tutorji, da bi na kompleksen in dinamičen način prispevali k razvoju pedagoške identitete.

Ključne besede: začetno usposabljanje, praksa, identiteta učitelja, tutorstvo, univerza 


\section{Introduction}

This article stems from the results of a competitive research project that took place during the 2016/7 and 2017/8 school years in the Faculty of Education, Translation, and Human Sciences (Facultad de Educación, Traducción $y$ Ciencias Humanas, FETCH) at The University of Vic-Central University of Catalonia in Spain. The UVic-UCC is a university with public vocation and private management located in Vic (Spain) and has a current total of 8,353 students. The research objective is to study how the university learning process and the work placement assignments at schools may contribute to the development of the teaching identity. This article is centred on the practicum, specifically within the training contexts of Physical Education and Inclusive Education and the more global and general perspective of the Bachelor's Degree in Primary Education. Eight students, eight school tutors, and eight university tutors took part in the research. During seminars, tutoring sessions, and school visits, data were collected using work placement memoirs, individual interviews, written observations, field notes, meeting records, and a discussion group.

The theoretical framework around the development of teacher identities will be presented in the next section, along with the rest of the research. The methodological perspective, the analysis, and the fieldwork discussion will follow. The ensuing section highlights the project results and proposals for improvement to consider during the practicum of the teachers' initial training. Finally, we will point out the most relevant conclusions regarding the construction of the teaching identity during the work placement programme.

\section{Teacher Identities: between the University and the School}

Learning how to be a teacher is a complex process that is nurtured throughout one's professional life. A general agreement exists that states that the teacher's job requires specific knowledge, skills, and mindsets and that the paths towards learning how to teach are varied (Ping et al., 2018). Being a teacher implies rethinking one's actions within the scholastic and social context and performing a continuing renovation of the educational undertaking. Talking about teacher identity implies bearing in mind the biographical development that each teacher uses to develop a feeling of belonging to their organisation, the degree of commitment, and the values that dictate their actions at the school (Beijaard et al., 2004; Day, 2012).

For this reason, the conducted research poses the challenge of studying how the university learning process and the work placement at schools may 
contribute to the development of teacher identities for future faculty members, understanding said concept as a dynamic, non-cumulative process in which reinterpreting and giving meaning to one's beliefs, values, and experiences become a priority (Flores \& Day, 2006). The complexity of identity as a construct lies in the use of subjectivity as a way of seeing, living, and feeling oneself (Day, 2004). Thus, the construction of the teacher identity becomes an organising principle in teachers' lives, developed from the multiplicity, the lack of continuity, and the social nature of identity (Akkerman \& Meijer, 2011).

Vidović \& Domović (2019) have found that the personal beliefs of primary education teachers-to-be may hinder the development of their professional beliefs. Therefore, they have expressed their need to rely on teacher support during initial training to understand and address the conflict between personal and professional beliefs during the practicum in initial teacher training (Domović et al., 2016). In this context, it is essential that 'initial teacher educators should leave more space for reflective approaches toward academic experiences of student teachers in order to address directly intuitive beliefs about teaching and learning and transform them into intended professional attitudes and values' (Vidović \& Domović, 2019 p. 135). As a consequence, the research we present regarding the construction of the teaching identity aims at promoting reflection on the educational practice from an early stage-initial teacher training - to contribute to the development of thoughtful teachers, in line with the idea expressed by Vujicić et al. (2015, p. 144): 'the teacher as a reflective practitioner is viewed as an initiator of change, an impetus for learning that also takes care of his/her own personal and professional development'.

We understand that contributing to the development of teacher identities means offering interpretation and re-interpretation processes of their own experiences, in addition to promoting environments that consider learning, in the vein of Hernández et al. (2020, p. 26), as 'a weft of relationships where the biographical and the corporeal are linked together, as well as the cognitive', in which each individual can perform their own processes of identification, representation and attribution, creating a spiral of continuous reconstruction (Branda \& Porta, 2012). This means that we propose investigating the development of teacher identity as a phenomenon of social interaction and one that is necessary to learn. From this perspective, university tutoring becomes relevant during this process. Therefore, we explore the term identity learning (Geijsel \& Meijers, 2005) as a construct that contributes to making sense of the formative processes of work placement (Beck \& Kosnik, 2000; Mule, 2006; Sorensen, 2014).

Along with Gairín-Sallán et al. (2019), we share the notion that the practicum helps the development of competences and teacher identities. Given 
the fact that experience in and of itself is not necessarily educational, the quality of the practitioner's interactions with school and university tutors is key to the learning processes of the soon-to-be teacher (Bullough et al., 2002; DarlingHammond, 2006; Novella, 2011; Solís et al., 2011). Staying in touch with professional reality is essential to guarantee a quality link between the teacher's work placement and the academic knowledge in the teacher's degree, but it is not enough. Transforming the practicum into a unifying bridge between school and university implies ensuring the students' accompaniment and their reflective practice, both individual and collective (Cebrián de la Serna, 2011; Rodríguez et al., 2011; Susinos-Rada \& Saiz-Linares, 2016). Likewise, the individual dimensions linked to a reflective practice are more easily acquired than the collaborative skills related to institutional participation, as shown by several researchers (Mendoza \& Covarrubias, 2014; Sancho-Gil et al., 2017).

Group seminars and individual tutoring sessions are the gathering spaces shared by the student and the university tutor. The seminar is understood as a stable, in-person, supervised interaction where referential contents are shared, and work placement experiences are exchanged. Seminars are known for being collective spaces for theoretical reflection upon practical matters, where the students are in constant dialogue with themselves, with others, and with the immersed context (Zabalza, 2002). University tutoring aims at providing quality and innovation to the support process. Tutoring eases the classroom access conditions, reinforces transition processes, improves permanence conditions, and contributes to the development of professional and life projects (Martínez Clares et al., 2014). The actual challenge is developing tutoring as a systematic, planned, integrated, intentional, continuous, dynamic process, and-above all-one recognised by academic qualifications and inside the institution. In this context, the university tutor is responsible for driving a dialogical process between institutions and students and reflecting upon the 'teacher self' of the student, the curriculum, and the teaching strategies to aid the learning process of the student body.

\section{The Work Placement Model in the Faculty of Education at UVic-UCC in Spain}

The practicum or work placement allows students to see a school environment in an experiential fashion and observe, analyse, and reflect on possible actual experiences of their future profession. It also serves the purpose of helping the student teacher's academic and professional training through a guided initiation of the teacher's exercise. In the Faculty of Education, the practicum is 
distributed in three of the four years of the Bachelor's Degree in Primary Education. Within the context of this research, the fourth-year practicum (Work Placement III) is a learning space where the student participates in school activities. The work placement course has a distinctive structure that differs from all the other courses and has the following characteristics: responsible teaching staff, group seminars, individual tutoring, and its completion schedule. The school teachers and the university professors tutor the student teachers. As its main objective, the Work Placement III course has to carry out an autonomous intervention connected to one of the specialisation options that each student has chosen (music, English, physical education, and inclusive education). During this period, the student analyses the context, the educational work carried out at schools, the teacher's roles and practices alongside the rest of the school staff, and the specialisation curriculum. The student must also reflect critically upon the methodologies and conceptions of the teaching and learning processes, the planning, development, and evaluation of an educational intervention aimed at primary school students-agreed upon by both tutors-and the relationship between academic knowledge and work placement. There is an explicit emphasis on student teachers' reflection centred around their work placement and learning process experiences. Each of these purposes is carried out at school and university, accompanied respectively by each tutor. The organisation of the Work Placement III course considers eight group seminar sessions held at the university, before and after the practicum. Moreover, individual tutoring is agreed on for each student, be it at the school or at the university.

The practicum model developed in the UVic-UCC Faculty is substantiated by what Novella (2011) defines as a participative, reflective, and dialogical process. It is intended that the students build a framework out of their work placement assignments-drawing from theoretical-practical elements to analyse and establish benchmarks-so as to consolidate contents and experiences that arise from their fieldwork. In this model, the work contents, which are gathered in a curriculum proposal, originate in the student's actions: actions that occur both at the schools and in the academic spaces of the university. In this approach, we understand reflection as a process that is far from being prescriptive (Mansvelder-Longayroux et al., 2007). The concern of improving the practicum from an institutional standpoint motivates us to take on research as a faculty, such as the one hereby presented, to address a complex subject that requires constant reviewing. Below, we detail the methodological decisions implemented in our research. 


\section{Methodological Decisions}

The research question that guided the study, focused on the fourth schoolyear work placement assignments, has been stated as follows: what inherent elements to the development of teacher identities are manifested during the practicum, and how can the role of university tutors benefit their advancement? In order to answer it, we have selected an interpretative and critical paradigm (Cohen et al., 2007; Lincoln et al., 2011), since it focuses on how the participants understand and comprehend their actions in a social context. Just as Moral stated (2016, p. 165), the compiled evidence is registered in a social context, and 'the arguments are built around the suppositions, criteria, beliefs, ideals, rules, etc., of the research participants, in an interactive process between the context, the investigated subjects, the method, the scenery, and the actors'. From this perspective, we intend to understand and interpret the actions that university tutors carry out during the work placement assignments to accompany the complex social processes of the school.

In this spirit, the study objectives presented in this article are:

1. To identify the elements that contribute to the learning process of teacher identity during a work placement, as told by the involved agents: students, school teachers, and university tutors.

2. To propose guidelines that improve the role of university tutors in work placement and the links between university and school in the development of teacher identities.

The research team, made up of eight university tutors, was organised through a continuous training seminar and evaluation of the teacher's practice. Each of the eight researchers tutored a student during the 2016-17 school year. In addition, a public call was launched for the degree students who specialised in physical education and attention to diversity to select the participants. In the end, eight students agreed to participate in the study while complying with all agreed commitments. Regarding ethical aspects, it is worth mentioning that all involved parties were previously informed about the project and had the chance to participate while knowing that their confidentiality was to be safeguarded during the entire process. Table 1 details the sample, while Table 2 shows the research instruments used for the task. 


\section{Table 1}

The sample

\begin{tabular}{|c|c|c|}
\hline Student (S) & School Tutor (ST) & University Tutor (UT) \\
\hline S1: Inclusive Education focus & $\begin{array}{l}\text { ST1: Attention to diversity spe- } \\
\text { cialisation. Previous experience } \\
\text { in work placement tutoring } \\
\text { (5-10 years) }\end{array}$ & $\begin{array}{l}\text { UT1: Pedagogue. } 20 \text { years of } \\
\text { experience in work placement } \\
\text { tutoring }\end{array}$ \\
\hline S2: Inclusive Education focus & $\begin{array}{l}\text { ST2: Attention to diversity spe- } \\
\text { cialisation. Previous experience } \\
\text { in work placement tutoring } \\
\text { ( } 5-10 \text { years) }\end{array}$ & $\begin{array}{l}\text { UT2: Sociologist with over } 10 \\
\text { years of experience in work } \\
\text { placement tutoring }\end{array}$ \\
\hline S3: Inclusive Education focus & $\begin{array}{l}\text { ST3: Attention to diversity spe- } \\
\text { cialisation. Previous experience } \\
\text { in work placement tutoring } \\
\text { ( } 5-10 \text { years) }\end{array}$ & $\begin{array}{l}\text { UT3: Educational psychologist. } \\
\text { Teacher with } 5 \text { years of expe- } \\
\text { rience. } 8 \text { years of experience in } \\
\text { work placement tutoring }\end{array}$ \\
\hline S4: Physical Education focus & $\begin{array}{l}\text { ST4: Physical education spe- } \\
\text { cialist. Previous experience in } \\
\text { work placement tutoring (10-15 } \\
\text { years) }\end{array}$ & $\begin{array}{l}\text { UT4: Pedagogue. } 25 \text { years of } \\
\text { experience in work placement } \\
\text { tutoring }\end{array}$ \\
\hline S5: Physical Education focus & $\begin{array}{l}\text { ST5: Physical education specia- } \\
\text { list. Previous experience in work } \\
\text { placement tutoring ( } 2-5 \text { years) }\end{array}$ & $\begin{array}{l}\text { UT5: Pedagogue. } 20 \text { years of } \\
\text { experience in work placement } \\
\text { tutoring }\end{array}$ \\
\hline S6: Physical Education focus & $\begin{array}{l}\text { ST6: Physical education spe- } \\
\text { cialist. Previous experience in } \\
\text { work placement tutoring (10-15 } \\
\text { years) }\end{array}$ & $\begin{array}{l}\text { UT6: Physical Education } \\
\text { teacher. Previous experience in } \\
\text { work placement tutoring (5-10 } \\
\text { years) }\end{array}$ \\
\hline S7: Physical Education focus & $\begin{array}{l}\text { ST7: Physical education specia- } \\
\text { list. Previous experience in work } \\
\text { placement tutoring ( } 2-5 \text { years) }\end{array}$ & $\begin{array}{l}\text { UT7: Physical Education teacher. } \\
\text { Previous experience in work } \\
\text { placement tutoring (10-15 } \\
\text { years) }\end{array}$ \\
\hline S8: Inclusive Education focus & $\begin{array}{l}\text { ST8: Attention to diversity spe- } \\
\text { cialisation. Previous experience } \\
\text { in tutoring practices (5-10 } \\
\text { years) }\end{array}$ & $\begin{array}{l}\text { UT8: Language Didactics } \\
\text { professor. } 7 \text { years of experience } \\
\text { in school teaching. } 9 \text { years of } \\
\text { experience in work placement } \\
\text { tutoring }\end{array}$ \\
\hline
\end{tabular}

\section{Table 2}

\section{Data collection techniques}

\begin{tabular}{ll}
\hline Participants & Data Collecting Instruments \\
\hline $\begin{array}{l}\text { 8 Students in the 4th school } \\
\text { year of the Degree (S) }\end{array}$ & $\begin{array}{l}\text { Work placement memoir: individual assignment written after school } \\
\text { work placement was over (M) } \\
\text { Written observations during follow-up seminar (WO) }\end{array}$ \\
\hline $\begin{array}{l}\text { 8 Teachers, school tutors } \\
\text { (ST) }\end{array}$ & $\begin{array}{l}\text { Individual interviews (II) } \\
\text { Discussion group (DG) }\end{array}$ \\
\hline $\begin{array}{l}\text { 8 Professors, university } \\
\text { tutors (UT) }\end{array}$ & $\begin{array}{l}\text { Field notes collected after tutoring sessions with students (FN) } \\
\text { Research project meeting records (MR) }\end{array}$ \\
\hline
\end{tabular}


Data analysis has been structured around three axes, all related to the development of teacher identity: the 'teacher self', the relationship and practical intervention of the students and the educational community, and the link between school and university knowledge. Each axis of analysis is configured according to the description and dimensions specified in Table 3, which have also guided the codification of the students', school tutors', and university tutors' collected data.

The dimensions emerged inductively from the data. The participants expressed their perspectives, points of view, and meanings regarding the analysed dimensions. Codified fragments have been interpreted in the light of the theoretical references that enable comprehending the complexity of the formative process and the educational actions carried out by the university tutors.

The outcome of this analysis and discussion is presented in the next section of this study, and after the results section, proposals for improvement focused on the university tutors within the context of the group seminars and the individual tutoring sessions are detailed.

\section{Table 3}

Axes of analysis: description and dimensions

\begin{tabular}{|c|c|c|}
\hline Axis of Analysis & Description & Dimensions \\
\hline The teacher self & $\begin{array}{l}\text { Aspects related to how } \\
\text { teachers learn, adapt, rebel, } \\
\text { or react to educational } \\
\text { situations }\end{array}$ & $\begin{array}{l}\text { - Significance of the teacher identity } \\
\text { - The impact of initial training on the } \\
\text { teacher's practice } \\
\text { - The teacher's craft }\end{array}$ \\
\hline \multirow{2}{*}{$\begin{array}{l}\text { To live and be a } \\
\text { part of the educa- } \\
\text { tional community: } \\
\text { feeling part of the } \\
\text { institution's reality } \\
\text { and the practical } \\
\text { intervention in the } \\
\text { classroom }\end{array}$} & $\begin{array}{l}\text { Aspects that relate the work } \\
\text { placement assignments to } \\
\text { a wider institutional context } \\
\text { in order to allow a deeper } \\
\text { interpretation of the practi- } \\
\text { cal context }\end{array}$ & $\begin{array}{l}\text { - Personal management of emotions } \\
\text { management at the school and in the } \\
\text { classroom }\end{array}$ \\
\hline & $\begin{array}{l}\text { Student reflections that in- } \\
\text { terpret their own experien- } \\
\text { ces and decipher, reference, } \\
\text { value, and integrate them } \\
\text { into their cognitive sche- } \\
\text { mes, and link them to the } \\
\text { work of the teaching staff }\end{array}$ & $\begin{array}{l}\text { - Analysis, reflection, and improvement of } \\
\text { the educational praxis } \\
\text { - Use of instruments for the reflective prac- } \\
\text { tice } \\
\text { - Reflections linked to the key elements of } \\
\text { professional teaching knowledge }\end{array}$ \\
\hline $\begin{array}{l}\text { Relationship } \\
\text { between the school } \\
\text { and the university }\end{array}$ & $\begin{array}{l}\text { Processes and knowledge } \\
\text { learned during the prac- } \\
\text { ticum that link academic } \\
\text { university knowledge with } \\
\text { practical school knowledge }\end{array}$ & $\begin{array}{l}\text { - Relationships between students, school } \\
\text { tutor, and university tutor } \\
\text { - Boundaries and opportunities in the relati- } \\
\text { onship between the } 3 \text { agents } \\
\text { - School-university coordination } \\
\text { - Adjustments and lack thereof between } \\
\text { academic university knowledge and prac- } \\
\text { tical school knowledge }\end{array}$ \\
\hline
\end{tabular}




\section{Analysis and Discussion}

In this section, we will present the fieldwork evidence, drawing from the three axes of analysis to exemplify the key elements that contribute to the learning process of identity through the statements of the three involved agents: students (S), school tutors (ST) and university tutors (UT).

\section{The Teacher Self: The School Tutor as a Role Model}

One of the key ideas emerging from the student subjects is the preoccupation over knowing and acting as good teachers in practical contexts. Said preoccupation, experienced as vulnerability (Flores \& Day, 2006), justifies the need to acquire organisational and educational strategies as a crucial component for the development of professional skills. Fieldwork shows how the expectations of the three implied agents vary; the technical aspects are the most relevant for the students, while the school tutors and the university tutors value the collaborative and the reflective aspects, respectively. Most of the students collect in their memoirs the insecurities experienced during their work placements. They convey that confidence is gained thanks to the trustful attitude of their school tutor. Along the lines of what has been said before, the teacher's viewpoint of the classroom is also fundamental in the following sense: 'My classroom tutor let me participate actively, and that has allowed me to feel increasingly confident of myself and of the work I've done' (S1_M).

The questioning of educational practices by the tutors, the schools, and the university helps the students to adjust their learning processes of the teacher identity through the consideration of dynamic and open situations where making unfinished and uncertain educational decisions is valued (Flores, 2001; Flores \& Day, 2006; Hauge, 2000). The research has allowed us to explore how the different agents experience the same process. We have found that students need to realise that educational actions carried out at the schools are not endgoals in and of themselves but rather complex, interpretable situations that lie beyond the limits of what is experienced in the school and classroom contexts.

Another identified element in the learning process of teacher identity is that, for most of the students, the teacher's model is by far the safest from an educational point of view. In this sense, they reveal how they integrate these performances when in session: 'I used some of the resources that the teacher used as routines inside the classroom, so the children already knew what they had to do at any given time' (S7_M). Thus, the students experience their university training-centred mostly on reflection upon educational models that substantiate the practical principles-but distanced from the schools themselves. 
Certainly, the university's proposals are not adequately connected to the subjective experience that each student goes through in the classroom and to what happens to them as apprentices from an emotional standpoint. Therefore, the complexity of identity as a construct lies in the use of subjectivity as a way of seeing, living, and feeling oneself (Day, 2004). Furthermore, learning is often associated with the relevant experiences that affect our lives (Carrasco \& Herraiz, 2020). Accordingly, evaluating the complexity involved in a learning process that stems from emotional and corporeal components, not just a cognitive one (Hernández et al., 2020), is a challenge for the university tutors.

Within this context, the students find significance in what they are able to successfully reproduce from the teacher models in the practical environment of the classroom.

\section{To Live and Be a Part of Practical Experiences Inside the Classroom}

During the classroom practice, the students face their limitations in the face of the actions implemented, which is why reinterpreting and making sense of their own beliefs, values, and experiences (Flores \& Day, 2006) long after their final evaluations have been conducted, is what is truly valuable to their learning processes. Implementing both dialogue processes and exchanges of experiences in work placement students is relevant when shared learning processes between peers are encouraged. This means that spaces such as small group seminars with work placement students are necessary to share reflections, emotions, doubts, uncertainties, and actions among the students, while they distance themselves from the work placement context and thus from the emotional component of the moment of action. It is about offering an environment where the students can develop processes of interpretation and reinterpretation of their experiences (Beijaard et al., 2004).

\section{Relationships: Agreements and Disagreements between the School and the University}

During the research, a distance between the work placement school context and the academic university context emerged. On the one hand, the students believe that the schools are where true knowledge is acquired, as shown in varying degrees by their analysed written memoirs. On the other hand, for some, the university classes during the practicum were far from their experienced reality, while for others, the school is where the university's theoretical contents become meaningful and help their professional development. 'This shows a lack of connection between the students' theory and practice' (ST4_DG). 
Another key aspect that arises from the collected data is the need for a joint effort between the school and the university that clearly establishes which actions favour the students' being welcomed into the school's context, which part they are granted, how they are supported so that they can observe and act in different moments and adopt different roles in the educational context. In this regard, it is relevant to define daily or weekly spaces of dialogue between the school teacher, the student, and-in some cases-the university tutor, so that they can share stances and inquiries about the experienced educational actions, enable continuous processes of construction and reconstruction, and gradually configure the teacher identity from teacher to student (Branda \& Porta, 2012).

The teacher identity is (re)shaped, at university and school, at different moments of the teacher's professional path. Listening to all agents involved in this process, based on their experiences and reflections, enables improving the students' accompaniment during their training, promote more explicit links between theory and practice, and offer tools that generate a more reflective view of the educational practices that take place in the classroom on a daily basis. Likewise, we should not forget the limits of the learning process of teacher identity, keeping in mind that the initial training is just the beginning of a professional journey that will last the entirety of the teacher's career.

\section{Results}

Regarding the key elements identified in the analysed data, we would like to highlight three results that contribute to the teacher identity learning process:

a) Supporting the learning of the 'teacher self' during the work placement. The university tutor should encourage the students' development of reflexive strategies that can shed light on educational events from different points of view: first, the sense a student makes of their intuition; second, the sense the school teachers have given them from their performances; and finally, what they have been able to share from the educational experiences that have presented them with challenges, conflict, uncertainty, surprise or even joy. In this manner, the learning process of the teacher identity, as stated by Geijsel \& Meijers (2005), requires a two-fold dialogue between the viewpoints and the objectives of the students and the conditions of the schools, which often come from the beliefs and actions of the school tutor. It is necessary to promote a dialogue that allows the sharing of different perspectives in dealing with a particular educational 
situation (Mule, 2006). This is a complex and uncertain process that cannot be solved by merely substituting the educational interventions of the student by those of the teacher. A rich and complex development process of teacher identity will be possible, in as much as the modelling - to which the student aspires — is understood as a path of inquiry.

b) The seminar should be a keystone for sharing reflections at university; it is a space where students can share their emotions regarding the educational experience and develop reflective processes. It is necessary that, out of the classroom experience, a global and deep reflection emerges intending to promote a more multifaceted view among students regarding their teacher role and the link between their profession's theoretical and practical aspects. This also implies fostering exchange processes between school and university tutors and the student, in addition to considering reflection as a process (Beauchamp \& Thomas, 2009; Geijsel \& Meijers, 2005). Research shows that, during the process, the spaces designated for joint reflection between all three agents (S, ST, UT) are scarce (limited exclusively to the initial and to the end-of-work-placement evaluations), although they are more common separately, be it in the school or in the university contexts.

c) Strengthening relationships between schools and the university. The cooperative relationship between the three agents intends to overcomenot without great effort-the institutional conditions (Gairín-Sellán et al., 2019; Zabalza, 2011) that often make the work possibilities between schools and universities more difficult. Thus, it is necessary that the legal, managerial, and labour factors enable a space where the three agents may negotiate professional, didactic, and personal factors.

\section{Proposals for Improvement}

Having concluded the research, the authors of this article-work placement university tutors who were fully involved in the accompaniment of students during their practicum-propose certain actions that will help university tutors both to contribute to the learning process of the teacher identity during work placement programmes and to enhance the links between university and schools. With no intention to generalise the results, this proposal presents elements of reflection that can improve the educational assignment of university tutors in the practicum.

In the university context, the seminar is the educational space that accompanies the students at three points: when the seminar is being conducted, 
on the follow-up of the work placement assignments, and in the final presentation of the written memoirs. The seminar is a space shared among tutors and students, sustained through time, allowing moments of joint reflection about the complexity of teacher professional development. From this perspective, we suggest acts of intervention that the university tutors can perform in order to address situations that are approached from the three analysis axes (the teacher self, the educational community and the intervention in the classroom, and the relationship between school knowledge and university knowledge).

The improvement actions regarding the seminar, work placement tutoring, and the written memoirs that are detailed hereunder are based on the results of our research.

\section{The Seminar's Initial Time Frame}

During the seminar, the students (S) share the educational situations that worry them the most with a group of peers: the context, the intervention, the didactic planning, or the school tutor (ST). The university tutor (UT) has the opportunity to address the students' misalignments, misunderstandings, surprises, concerns, or uncertainties through actions that enable additional spaces of reflection and exchange between the three agents, such as:

- Observation spaces for the UT at the schools so that the student can fit in better in the school's educational community.

- $\quad$ Exchange of experiences with the ST so as to understand the complexity of life at the school and in the classroom. This will lead to dealing with management and learning process aspects within the institutional and classroom contexts.

- Analysis of situations that can be discussed with other university professors from other areas of knowledge in order to address the continuities and discontinuities the student may experience between the academic university knowledge and the practical school knowledge.

- Exchange of educational proposals among the seminar students to improve the initial training of the teacher's practice.

\section{Work Placement Follow-up}

During this period, the proposed actions strive to improve the relationship between the university and school tutors.

- Improving communication during the work placement assignments through different methods eliminates any obstacles between the three agents and strengthens the bond between the university's academic knowledge and the school's practical knowledge; 
- Recovering and agreeing on the work plan before the work placement begins in order to organise the student's objectives, interventions, and evaluations. This coordination between agents and institutions will provide a more stable environment for the initial training of the student;

- Agreeing on the joint evaluation of the student and doing so in front of all three agents in order to improve the coordination of the student's training process;

- Arranging the delivery of the student's written memoirs to the school to formalise the commitment between the institutions involved.

In terms of the relationship between the three agents: student (S), school tutor (ST) \& university tutor (UT), the UT has the following responsibilities:

- Promoting deliberation around the didactic proposal the student will carry out in the school's classroom so that flexibility and (re)planning are posed as key aspects of the learning process of the student's teacher identity.

- Exchanging the student's work placement reflections (field diary, meaningful events, tutoring sessions, etc.) so that they may become instruments that are used habitually and on a daily basis during the work placement. In addition, the UT must share and propose literature that may help the student during his/her training process.

\section{Final Presentation of the Written Memoirs}

The memoirs are written documents that the students present after finishing their practicum. In their creation process, the university tutors (UT) can: - Propose a more open document that includes a wide array of languages, such as narrative, biographical, artistic, among others. For example, through the compilation of evidence in a learning process folder, agreed upon by the teaching staff of the different areas that are part of the Bachelor's Degree in Primary Education, and linked to the educational communities of the work placement schools. Thus, more direct relationships can be established between academic university references and school practices.

- Review the responsibilities of the involved agents during the practicum. It is a challenge for the Faculty to explore the different encounter possibilities with the work placement schools so as to chart joint work lines and to identify and agree on shared commitments and projects that may contribute to the learning process of the teacher identity of the students during their initial training. 
To summarise, we would like to underscore the need to rethink certain issues present in the practicum of the Bachelor's Degree in Primary Education, to contribute to the enhancement of the key aspects related to the development of the teacher identity from the university and the work placement schools, with an emphasis on the UT's responsibilities and actions.

\section{Conclusions}

The results have allowed us to identify the elements that contribute to the development of teacher identity and, based on these, to rethink various aspects of the practicum, making proposals for improvement. The role of the university tutor is highlighted as a key element in the mediation between students and school contexts and communities. We agree with Sancho-Gil et al. (2017, p. 322) in their assessment that, in recent decades, initial training in Spain has improved: 'It has moved from a rather traditional, craft-oriented, and ideological model towards a more academic and professional one, reaching the status of a bachelor's degree with the implementation of the European Higher Education Area (EHEA)'. Furthermore, the tasks performed by the university tutors need to be strengthened in order to improve the students' learning process of their identity (Geijsel \& Meijers, 2005).

Shaping future teachers within the complex context of the profession implies outgrowing the boundaries of technical and organisational knowledge and integrating elements of reflection and re-interpretation of the classroom and school experiences, as well as making collective sense of the practical experiences through processes of collaboration based on student-tutor trust. Furthermore, the difficulty in coordinating the educational schedules of the schools and the university is added to the organisational complexity of all the involved agents. However, this research has shown the importance of improving university training spaces and specifically the practicum period to demonstrate the importance of integrating reflective learning, understood as an emotional, bodily, and cognitive process (Hernández et al., 2020) that develops processes of self-knowledge as well as knowledge of others and the world (Akkerman \& Meijer, 2011; Charlot, 2007). Lastly, we would like to highlight the improvement proposals specified above, which are based on the results of our research, as they may positively impact the field training of university tutors. Offering tools that encourage students' reflection, negotiation, and decisionmaking when confronted with the tensions of the teaching profession is crucial to the complex and dynamic development of the teaching identity through the practicum. 


\section{Acknowledgements}

This paper is part of the project 'Building Teacher Identity from Practice and Research in the Classroom: the Role of the Practicum and Final Degree Assignment (FDA) in Teacher Education'. Ref: 2015ARMIFooo40. The project is funded by the Catalan Government.

\section{References}

Akkerman, S. F., \& Meijer, P. C. (2011). A dialogical approach to conceptualizing teacher identity. Teaching and Teacher Education, 27(2), 308-319. https://doi.org/10.1016/j.tate.2010.08.013 Beauchamp, C., \& Thomas, L. (2009). Understanding teacher identity: An overview of issues in the literature and implications for teacher education. Cambridge Journal of Education, 39(2), 175-189. https://doi.org/10.1080/03057640902902252 Beijaard, D., Meijer, P. C., \& Verloop, N. (2004). Reconsidering research on teachers' professional identity. Teaching and Teacher Education, 20(2), 107-128. https://doi.org/10.1016/j.tate.2003.07.001 Beck, C., \& Kosnik, C. (2000). Associate teachers in pre-service education: clarifying and enhancing their role. Journal of Education for Teaching, 26(3), 207-224. https://doi.org/10.1080/713676888 Branda, S., \& Porta, L. (2012). Maestros que marcan. Biografía personal e identidad profesional en docentes memorables [Teachers who mark. Personal biography and professional identity in memorable teachers]. Profesorado. Revista de Currículum y Formación Del Profesorado, 16(3), 231-243.

Bullough, R. V., Young, J., Erickson, L., Birrell, J. R., Clark, D. C., Egan, M. W., Berrie, C. F., Hales, V., \& Smith, G. (2002). Rethinking field experience: partnership teaching versus single-placement teaching. Journal of Teacher Education, 53(1), 68-80. https:///doi.org/10.1177/0022487102053001007 Carrasco, S., \& Herraiz, F. (2020). El caso del instituto Bonavista: el aprender corporeizado y biográfico [The case of the Bonavista Institute: embodied and biographical learning]. In F. Hernández, E. Aberasturi, J. M. Sancho, \& J. M. Correa (Eds.), ¿Cómo aprenden los docentes? Tránsitos entre cartografías, experiencias, corporeidades y afectos (pp. 125-135). Octaedro. Cebrián de la Serna, M. (2011). Supervisión con e-portafolios y su impacto en las reflexiones de los estudiantes en el Prácticum: estudio de caso [Supervision with e-portfolios and their impact on the reflections of students in the practicum: Case study]. Revista de Educación, 354, 183-208.

Cohen, L., Manion, L., \& Morrison, K. (2007). Research methods in education. Routledge.

Charlot, B. (2007). La relación con el saber: elementos para una teoría [The relationship with knowledge: Elements for a theory]. Libros del Zorzal.

Darling-Hammond, L. (2006). Constructing 21st-century teacher education. Journal of Teacher Education, 57(3), 300-314.

Day, C. (2004). A passion for teaching. Routledge/Farmer.

Day, C. (2012). The new lives of teachers. Teacher Education Quarterly, 39(1), 7-26. https://doi.

org/10.1007/978-94-6209-240-2_4 
Domović, V., Vizek Vidović, V., \& Bouillet, D. (2016). Student teachers' beliefs about the teacher's role in inclusive education. European Journal of Special Needs Education, 32(2), 175-19o. https://doi.org/10 $.1080 / 08856257.2016 .1194571$

Flores, M. A. (2001). Person and Context in Becoming a New Teacher. Journal of Education for

Teaching, 27(2), 135-148. https://doi.org/10.1080/02607470120067882

Flores, M. A., \& Day, C. (2006). Contexts which shape and reshape new teachers' identities: A multi-perspective study. Teaching and Teacher Education, 22(2), 219-232. https://doi.org/10.1016/j. tate.2005.09.002

Gairín-Sallán, J., Díaz-Vicario, A., del Arco Bravo, I., \& Flores Alarcia, Ó. (2019). Efecto e impacto de las prácticas curriculares de los grados de educación infantil y primaria: la perspectiva de estudiantes, tutores y coordinadores [Effect and impact of the curricular practices of the infant and primary education grades: The perspective of students, tutors and coordinators]. Educación, XX1, 22(2), 17-43. https://doi.org/10.5944/educXX1.21311

Geijsel, F., \& Meijers, F. (2005). Identity learning: The core process of educational change.

Educational Studies, 31(4), 419-430. https://doi.org/10.1080/03055690500237488

Hauge, T. E. (2000). Student teachers' struggle in becoming professionals: Hopes and dilemmas in teacher education. In C. Day, A. Fernandez, T. E. Hauge, \& J. Moller (Eds.), The life and work of teachers. International perspectives in changing times (pp. 159-172). Falmer Press.

Hernández, F., Aberasturi, E., Sancho J. M., \& Correa, J.M. (2020) ¿Cómo aprenden los docentes? Tránsitos entre cartografías, experiencias, corporeidades y afectos [How do teachers learn? Transits between cartography, experiences, corporeality and affections]. Octaedro.

Lincoln, Y. S., Lynham, S. A., \& Guba, E. G. (2011). Paradigmatic controversies, contradictions, and emerging confluences, revisited. In N. K. Denzin, \& Y. S. Lincoln (Eds.), The Sage handbook of qualitative research (pp. 97-128). Sage.

Mansvelder-Longayroux, D. D., Beijaard, D., \& Verloop, N. (2007). The portfolio as a tool for stimulating reflection by student teachers. Teaching and Teacher Education, 23(1), 47-62. https://doi. org/10.1016/j.tate.2006.04.033

Martínez Clares, P., Pérez Cusó, P., \& Martínez Juárez, M. (2014). Una (re)visión de la tutoría universitaria en los estudios de Grado [A (re)vision of university tutoring in undergraduate studies]. REDU. Revista de docencia universitaria, 12(1), 269-305. https://doi.org/10.4995/redu.2014.6425 Mendoza, M., \& Covarrubias, C. G. (2014). Competencias profesionales movilizadas en el prácticum: percepciones del estudiantado del grado de maestro en educación primaria [Professional skills applied in the practicum: Pre-service primary school teacher student perceptions]. Actualidades Investigativas en Educación, 14(3) 1-24. https://doi.org/10.15517/aie.v14i3.16089 Moral, C. (2016). Estrategias para resistir a la crisis de confianza en la investigación cualitativa actual [Strategies to resist the crisis of confidence in current qualitative research]. Educación, XX1, 19(1), 113-135. https://doi.org/10.5944/educxx1.15582

Mule, L. (2006). Preservice teachers' inquiry in a professional development school context: Implications for the practicum. Teaching and Teacher Education, 22(2), 205-218. https://doi. 
org/10.1016/j.tate.2005.09.011

Novella, A. M. (2011). Prácticum en re-construcción: Tejiendo colectivamente un modelo de prácticas desde la innovación [Practicum in re-construction: Collectively weaving a model of practices from innovation]. Revista de Docencia Universitaria, 9(3), 259-280. https://dialnet.unirioja. es/servlet/articulo? codigo $=4019481$

Ping, C., Schellings, G., \& Beijaard, D. (2018). Teacher educators' professional learning: A literature review. Teaching and Teacher Education, 75, 93-104. https://doi.org/10.1016/j.tate.2018.06.003 Rodríguez, A., R. M., Esteban, R., Aranda, M., Blanchard, C., Domínguez, P., González, P. \& Romero, et al. (2011). Coaching reflexivo entre iguales en el Prácticum de la formación de maestros [Reflective coaching between peers in the practicum of teacher training]. Revista de Educación, 355, 355-379. https://doi.org/10.4438/1988-592X-RE-2011-355-028

Sancho-Gil, J. M., Sánchez-Valero, J. A., \& Domingo-Coscollola, M. (2017). Research-based insights on initial teacher education in Spain. European Journal of Teacher Education, 40(3), 310-325. https:// doi.org/10.1080/02619768.2017.1320388

Solís, M. C., Núñez, C., Contreras, I., Rittershaussen, S., Montecinos, C., \& Walker, H. (2011). Condiciones de la formación práctica de los futuros profesores [Conditions for the practical training of future teachers]. Estudios Pedagógicos (Valdivia), 37(1), 127-147. https://doi.org/10.4067/so71807052011000100007

Susinos-Rada, T., \& Saiz-Linares, A. (2016). Los problemas pedagógicos son mis aliados. El practicum como un proceso de reflexión e indagación colaborativa [Pedagogical problems are my allies. The practicum as a process of reflection and collaborative inquiry]. Revista de Investigación en Educación, 14(1), 5-13. https://repositorio.unican.es/xmlui/bitstream/handle/10902/12171/ ProblemasPedagogicosAliados.pdf? sequence $=1$ Sorensen, P. (2014). Collaboration, dialogue and expansive learning: The use of paired and multiple placements in the school practicum. Teaching and Teacher Education, 44, 128-137. https://doi. org/10.1016/j.tate.2014.08.010

Vidović, V., \& Domović, V. (2019). Development of teachers' beliefs as a core component of their professional identity in initial teacher education: A longitudinal perspective. Center for Educational Policy Studies Journal, 9(2), 119-138. https://doi.org/10.26529/cepsj.720 Vujicić, L., Boneta, Z., \& Ivković, Z. (2015). The (Co-)Construction of Knowledge within Initial Teacher Training: Experiences from Croatia. Center for Educational Policy Studies Journal, 5(2), 139-157. https://www.cepsj.si/index.php/cepsj/article/view/146

Zabalza, M. A. (2002). La enseñanza universitaria: el escenario y sus protagonistas [University education: The stage and its protagonists]. Narcea.

Zabalza, M. A. (2011). El prácticum en la formación universitaria: Estado de la cuestión[Practicum in university education: State of the art]. Revista de Educación, 354, 21-43. http://hdl.handle. 


\section{Biographical note}

Gemma Torres-Cladera, PhD, is a lecturer in the area of Physical Education in the Faculty of Education, Translation and Human Sciences at the University of Vic - Central University of Catalonia (UVic-UCC). She is also a researcher at GREF - Physical Education Research Group at UVic-UCC. Her research interests include initial and in-service teacher training in different educational contexts. She is involved in research methodologies and also in participatory and inclusive evaluation to do research with people.

Núria Simó-GIL, $\mathrm{PhD}$, is a senior lecturer in the field of Pedagogy on the Faculty of Education, Translation and Human Sciences at the University of Vic - Central University of Catalonia. She is also researcher of the GREUV Educational Research Group at the UVic-UCC. Her research interests include training of social educators and teachers, democratic schools, and processes of social and educational inclusion with young people. She is involved in participatory research methodologies to do research with people and not about people.

Laura Domingo-Peñafiel, PhD, is a lecturer in the field of Pedagogy on the Faculty of Education, Translation and Human Sciences at the University of Vic - Central University of Catalonia. She is also researcher of the GREUV - Educational Research Group at the UVic-UCC. Her main areas of research interests are: training teachers, inclusion, democratic and rural schools. It is focused on multigrade and place-based teaching in a rural education framework.

Vanesa Amat-Castells, PhD, is a lecturer in the field of Didactics of Language and Literature on the Faculty of Education, Translation and Human Sciences at the University of Vic - Central University of Catalonia. Her research interests include teaching and learning language and literature in the early years of education, developing the training of literary readers and as well teacher education and their professional development. 